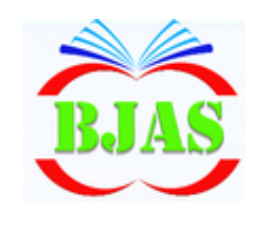

ISSN $1814-5868$
Available online at http://bjas.bajas.edu.iq https://doi.org/10.37077/25200860.2020.32.1.02 College of Agriculture, University of Basrah

\section{Basrah Journal of Agricultural Sciences}

E-ISSN: 2520-0860

\title{
Impact of Feeding Tea Leaves Saponins on Some Productive and Serum Biochemical Parameters of Awassi Lambs
}

\author{
Rasheed H. Abdullah \& Hanaa A. J. Al-Galbi* \\ Department of Animal Production, College of Agriculture, University of Basrah, Iraq \\ *Corresponding author: hanaa.jaba@gmail.com \\ Received 25 March 2020; Accepted 3 May 2020; Available online 23 June 2020
}

\begin{abstract}
The study was conducted in one of the private fields of Wasit Governorate for the period from $22 / 1 / 2019$ to $11 / 5 / 2019$. The study aimed to investigate the impact of feeding different levels of saponins on the productive performance of Awassi lambs. Sixteen Awassi lambs aged three-four months with an average weight of $23.68 \mathrm{~kg}$ were used. The lambs were randomly divided into four experimental treatments with four animals for each. The diet provided at $3 \%$ of the body weight. The feed was provided with two meals ( 8 am and $4 \mathrm{pm}$ ). The $1^{\text {st }}$ treatment was control (without addition), while in the $2^{\text {nd }}, 3^{\text {rd }}$, and $4^{\text {th }}$ treatments, saponins was added at level of 60,120 and $180 \mathrm{mg} \cdot \mathrm{kg}^{-1} \mathrm{DM}$ feed respectively. Adding saponins at $180 \mathrm{mg} \cdot \mathrm{kg}^{-1} \mathrm{DM}$ increased the final body weight at the second and third months of the study with 34.35 and $40.36 \mathrm{~kg}$, respectively. Total gain was increased in this treatment from $15.03 \mathrm{~kg}$ in control to $17.47 \mathrm{~kg}$. Feed conversion ratio of the same treatment was 5.52 as compared with $6.24 \mathrm{~kg}_{\mathrm{kg}} \mathrm{kg}^{-1}$ feed for the control treatment. Glucose and protein concentrations in the serum also showed an improvement due to the addition of saponins. Values were, $57.24 \mathrm{mg} .100 \mathrm{ml}^{-1}$ and $4.83 \mathrm{~g} .100 \mathrm{ml}^{-1}$ respectively. Those of control group were $51.86 \mathrm{mg} .100 \mathrm{~m}^{-1}$ and $4.62 \mathrm{~g} .100 \mathrm{ml}^{-1}$ respectively. Cholesterol concentration in the serum was not affected by addition of different levels of saponins. It can be concluded that addition of saponins at $180 \mathrm{mg}$. $\mathrm{kg}^{-1}$ feed improved body weight, gain, feed conversion ratio and some serum biochemical parameters.
\end{abstract}

Keywords: Awassi lambs, Serum, Saponins, Gain, Conversion.

\section{Introduction}

General concerns about chemical compounds that are used as feed additives have increased, and in this context safer alternatives have been found including the use of secondary compounds produced by plants such as saponins, essential oils, tannins, etc. (Khalifa et al., 2014). There is a growing interest by researchers in the field of nutrition about the use of plant extracts as natural additives in their efforts to modify rumen fermentation and make it more efficient in digesting fiber and improving the efficiency of feed use or reducing protein degradation and thus increasing its flow to the duodenum, improving the quality of meat, improving nutrient digestibility while reducing methane and 
ammonia production as well as emissions (Sliwinski 2004; Szumacher-Strabel \& Cieślak, 2010). Several measures have been considered to manipulate the production of gases, as plant extracts have been found to have more integrated benefits or are considered to be an effective way to reduce methane and ammonia emission compared to chemical additives such as antibiotics. Plant extracts can be combined as a growth enhancer or anti-inflammatory, fungus, infection and poisoning (Sun et al., 2017).

Among the nutritional solutions developed are the use of saponins, which are usually high in tropical plants, promising natural materials to reduce ammonia and methane emissions and to modify rumen fermentation (Budan et al., 2013).

Liu et al. (2018) found significant difference in final body weight when feeding lambs diets with saponins at different levels (2000 and 4000) mg.kg ${ }^{-1}$ dry matter (42.5 and $42.4 \mathrm{~kg}$, respectively), compared with the control treatment which recorded $39.6 \mathrm{~kg}$. Liu et al. (2019) indicated when adding two levels of saponins $\left(0\right.$ and $2.0 \mathrm{~g}$. head ${ }^{-1}$ per day to sheep diets, there was a significant increase in the final weight compared to the control treatment. However, adding saponins at different levels did not significantly affect the amount of feed consumed (Liu et al., 2018; 2019). Aazami et al. (2013) indicated that adding saponins at different levels $\left(0,100\right.$ and $200 \mathrm{mg}$. $\mathrm{kg}^{-1}$ dry matter) to sheep diets, there were no significant differences in the concentration of both glucose and triglycerides in all levels of addition while a significant decrease was found in cholesterol concentration in the third treatment compared with the control treatment.
The current study aimed to investigate the impact of feeding Awassi lamb different levels of tea seed saponin on body weight, gain and some serum biochemical parameters.

\section{Materials \& Methods}

\section{Extraction of saponins from tea leaves}

Saponin from tea leaves was extracted following the method developed by Hussien \& Awad (2014). In brief, tea leaves were collected, gently cleaned, dried, then grinded. Dissolve $30 \mathrm{~g}$ of crushed powder with $450 \mathrm{ml}$ of $99.8 \%$ methanol for a period of 7 days under room temperature. After filtering, the extracted liquid evaporated under low pressure in a rotary evaporator until thick residual is formed. The residual was then washed with petroleum ether to remove chlorophyll and fatty substances, and the process continued until the residual became colorless. Dissolving the residual is repeated in $100 \mathrm{ml}$ of $99.8 \%$ methanol and added to the resulting solution, diethyl ether. A yellowish residual will be formed from saponins and the process of adding diethyl ether will continue until the sedimentation process was stopped. The resulted compound was dried by continuous stirring at the laboratory temperature to produce the raw extract which was estimated to be $4.3 \mathrm{~g}$ of saponins.

\section{Productive traits}

Body weight $(\mathrm{kg})$ was recorded by normal balance for lambs. Growth rate gain $(\mathrm{kg})$ was estimated as the difference between initial and final body weights. Total feed consumption $(\mathrm{kg})$ was the difference between offered feed and the residual. Feed conversion ratio was estimated by dividing feed consumed on total gain $\left(\mathrm{kg} \cdot \mathrm{kg}^{-1}\right)$. 


\section{Serum biochemical parameters}

Serum glucose, total protein, cholesterol and triglycerides were determined using kit produced by French company (BIOLABO SA) as:

$$
\begin{aligned}
& \text { Glucose }\left(\mathrm{mg} / 100 \mathrm{~cm}^{\wedge} 3\right)=\left(\frac{\text { sample reading }}{\text { standard solution }}\right) * 5.32 \\
& \text { Total protein }\left(\mathrm{g} / 100 \mathrm{~cm}^{\wedge} 3\right)=\left(\frac{\text { sample reading }}{\text { standard solution }}\right) * 6 \\
& \text { Cholesterol }\left(\mathrm{mg} / 100 \mathrm{~cm}^{\wedge} 3\right)=\left(\frac{\text { sample reading }}{\text { standard solution }}\right) * 200 \\
& \text { Triglycerides }\left(\mathrm{mg} / 100 \mathrm{~cm}^{\wedge} 3\right)=\left(\frac{\text { sample reading }}{\text { standard solution }}\right) * 200
\end{aligned}
$$

\section{Feeding groups}

Animals were distributed into four feeding treatments. The first treatment was a control (no addition), in which diet included $50 \%$ barley, $20 \%$ wheat bran, $20 \%$ corn, $7.5 \%$ soya bean meal and $2.5 \%$ vitamin and minerals. The second treatment was a control ration plus 60 mg. $\mathrm{kg}^{-1}$ feed of tea saponin. The third treatment was a control ration plus $120 \mathrm{mg} \cdot \mathrm{kg}^{-1}$ feed of tea saponin. The fourth treatment was a control ration plus $180 \mathrm{mg} \cdot \mathrm{kg}^{-1}$ feed of tea saponin. Wheat straw was offered ad libitum for all treatments.

\section{Statistical analysis}

Data were analyzed according to a completely randomized design. Treatments effects on studied traits were analyzed using one-way ANOVA design (SPSS, 2016, version 24). The significant differences among means were compared by least significant test within the same statistical packages. Significant level considered as 0.05. Each treatment had three replicates.

\section{Results \& Discussion}

\section{Final weight and total gain}

Table (1) shows significant differences $(\mathrm{P}<0.05)$ among the means of both final weights and total gain of lambs in the experimental treatments. Statistical analysis showed no significant differences in the final weight and gain for all treatments in the first month. The significant differences were existed $(\mathrm{P}<0.05)$ in the second and third months of the experiment, where the fourth treatment (saponins at a level of $180 \mathrm{mg}$ ) in the second month recorded higher significant increase $(\mathrm{P}<0.05)$ in the final weight $(34.35 \mathrm{~kg})$ as compared with the first and second treatments (31.70 and $31.90 \mathrm{~kg}$, respectively). Results also showed a significant superiority $(\mathrm{P}<0.05)$ for the second, third and fourth treatments for which saponins were added at level of 60, 120 and $180 \mathrm{mg} \cdot \mathrm{kg}^{-1}$ feed, respectively, in the final weight at the third month $(38.50,39.83$ and $40.36 \mathrm{~kg}$ respectively) as compared with the control $(37.93 \mathrm{~kg})$. The fourth treatment 
recorded higher $(\mathrm{P}<0.05)$ significant increase $(17.74 \mathrm{~kg})$ in total gain as compared with the control and second treatments (15.03 and 15.66 $\mathrm{kg}$, respectively). However, adding saponin at $120 \mathrm{mg} \cdot \mathrm{kg}^{-1}$ showed similar gain as that of 180 mg.kg-1 $(16.69 \mathrm{~kg})$. the improvement in both body weight and total gain may be due to the effective role of saponins in improving the rumen condition by providing a suitable $\mathrm{pH}$ for the growth of microorganisms that improve the digestion and absorption of nutrients. Saponin also may serves to reduce ammonia and thus increases the flow of protein to the intestine, and as a result improves body weight and weight gain. These results are consistent with
Liu et al. (2018), they used saponins at different levels $\left(0,500,1000,2000\right.$ and 4000) mg. $\mathrm{kg}^{-1}$ dry matter, and found a significant increase $(\mathrm{P}<0.05)$ in the final weight of the fourth and the fifth treatments as compared with other treatments. Liu et al. (2019) also observed a significant increase $(\mathrm{P}<0.05)$ in the final weight of sheep due to feeding diets containing $2 \mathrm{~g}$. head $^{-1}$ per day of saponins as compared with the control treatment. However, Mao et al. (2010) and Nasri et al. (2011) did not observe significant differences in the final weight and the gain due addition of saponins to lambs' diets.

Table (1): Effect of adding different levels of saponins on body weight and the total gain (kg. head ${ }^{-1}$ ) of Awassi lambs at different periods (Mean \pm SD).

\begin{tabular}{|l|c|c|c|c|c|}
\hline \multirow{2}{*}{$\begin{array}{l}\text { Treatments } \\
\text { (Saponin level) }\end{array}$} & \multicolumn{4}{|c|}{ Body weight $(\mathrm{kg})$} & \multirow{2}{*}{ Total gain $(\mathrm{kg})$} \\
\cline { 2 - 5 } & Initial & $1^{\text {st }}$ month & $2^{\text {nd }}$ month & $3^{\text {rd }}$ month & \\
\hline 0 mg.kg-1 feed & 22.90 & 26.92 & $31.70^{\mathrm{b}}$ & $37.93^{\mathrm{b}}$ & $15.03^{\mathrm{b}}$ \\
$($ Control $)$ & \pm 1.21 & \pm 0.13 & \pm 0.30 & \pm 0.90 & \pm 0.50 \\
\hline \multirow{2}{*}{$60 \mathrm{mg} \cdot \mathrm{kg}^{-1}$ feed } & 22.83 & 27.13 & $31.90^{\mathrm{b}}$ & $38.50^{\mathrm{a}}$ & $15.66^{\mathrm{b}}$ \\
& \pm 0.28 & \pm 0.41 & \pm 0.60 & \pm 0.78 & \pm 0.49 \\
\hline \multirow{2}{*}{$120 \mathrm{mg} \cdot \mathrm{kg}^{-1}$ feed } & 23.14 & 27.40 & $33.30^{\mathrm{ab}}$ & $39.83^{\mathrm{a}}$ & $16.69^{\mathrm{ab}}$ \\
& \pm 1.39 & \pm 1.24 & \pm 1.68 & \pm 1.89 & \pm 0.81 \\
\hline \multirow{2}{*}{$180 \mathrm{mg} \cdot \mathrm{kg}^{-1}$ feed } & 22.50 & 27.33 & $34.35^{\mathrm{a}}$ & $40.36^{\mathrm{a}}$ & $17.74^{\mathrm{a}}$ \\
& \pm 1.01 & \pm 0.62 & \pm 0.58 & \pm 1.21 & \pm 0.65 \\
\hline
\end{tabular}

- Vertically different letters mean significant differences at $P<0.05$ level.

Feed consumption and feed conversion ratio

Table (2) shows the amount of feed consumed and the feed conversion ratio. Statistical analysis was not performed due to group feeding. Highest amount of feed was consumed by lambs in the fourth treatment throughout the trial period $(97.98 \mathrm{~kg})$ followed by the third $(97.13 \mathrm{~kg})$. The least amount of feed was consumed by lambs the first (control) and second treatments throughout the trial period (93.82 and 94.52 $\mathrm{kg}$, respectively).

Regarding feed conversion, the table showed that the best value was recorded by lambs in the fourth treatment (5.52) followed by those in the third treatment (5.82 $\mathrm{kg}$ feed. $\mathrm{kg}^{-1}$ weight gain). In both 
treatments feed conversion ratio was better than that recorded by lambs in the first and the second treatments $(6.24$ and $6.03 \mathrm{~kg}$ feed. $\mathrm{kg}^{-1}$ weight gain) respectively. This may be due to the fact that addition of saponin improved the rumen condition, by stimulation the efficiency of microbial growth and the inhibition of protein degradation in the rumen, which in turn has been reflected in the efficiency of utilization of the metabolizable protein reaching the intestine. The results were not in consistent with those reported by Mao et al. (2010) and Nasri et al. (2011), in which no differences in the amount of feed consumed and the feed conversion ratio due to addition of saponins to lambs' diets. Liu et al. (2018 \& 2019) found no significant effect of saponin on feed consumption and feed conversion ratio by sheep.

Table (2): Effect of adding different levels of saponins on feed consumed and feed conversion ratio.

\begin{tabular}{|l|c|c|}
\hline Treatments (saponin level) & Feed consumption (kg) & $\begin{array}{c}\text { Feed conversion ratio (kg } \\
\text { feed. } \mathrm{kg}^{-1} \text { weight gain) }\end{array}$ \\
\hline 0 mg.kg & 6.24 \\
\hline $60 \mathrm{mg} \cdot \mathrm{kg}^{-1}$ feed (Control) & 93.82 & 6.03 \\
\hline $120 \mathrm{mg} \cdot \mathrm{kg}^{-1}$ feed & 94.53 & 5.82 \\
\hline $180 \mathrm{mg} \cdot \mathrm{kg}^{-1}$ feed & 97.14 & 5.52 \\
\hline
\end{tabular}

There are no significant differences among different treatment means.

\section{Serum biochemical parameters}

\section{Glucose}

Table (3) shows that there were no significant differences $(\mathrm{P}<0.05)$ in the mean blood glucose concentration among experimental treatments due to addition of saponins at the following levels $(0,60,120$ and 180) mg.kg-1 dry matter at the first month. Values were 50.41, 51.27, 52.38 and $51.14 \mathrm{mg} .\left(100 \mathrm{~cm}^{3}\right)^{-1}$, respectively.

However, the table shows the presence of significant differences $(\mathrm{P}<0.05)$ in the mean serum concentration of glucose at the second month. The fourth treatment was significantly superior $(\mathrm{P}<0.05)$ with 57.24 $\mathrm{mg} \cdot 100^{-1} \mathrm{~cm}^{3}$ as compared with the $1^{\text {st }}, 2^{\text {nd }}$ and $3^{\text {rd }}$ treatments, values were $51.86,53.13$, and $53.60 \mathrm{mg} \cdot 100^{-1} \mathrm{~cm}^{3}$, respectively. Table (3) also shows the presence of significant differences $(\mathrm{P}<0.05)$ in the serum blood glucose concentration for the third, and the fourth treatments $\left(59.00\right.$ and $60.61 \mathrm{mg} \cdot 100^{-1}$ $\mathrm{cm}^{3}$, respectively) as compared with the first and second treatments (55.01 and 55.09 mg. $100^{-1} \mathrm{~cm}^{3}$, respectively). These results were not in agreement with those obtained by Aazami et al. (2013) due to addition of saponins at different levels $(0,100 \& 200)$ mg. $\mathrm{kg}^{-1}$ dry matter to sheep diets, where, 
they noticed no significant differences $(\mathrm{P}<0.05)$ in the concentration of glucose in all levels of addition.

\section{Total protein}

Results of table (3) shows the presence of significant differences $(\mathrm{P}<0.05)$ in the concentration of protein among the different experimental treatments. The fourth treatment was significantly superior
$(\mathrm{P}<0.05)$ at the first month $\left(4.83 \mathrm{~g} .100 \mathrm{~cm}^{3-}\right.$

$\left.{ }^{1}\right)$ as compared with the first \& second treatments $\left(4.65\right.$ and 4.62 g.100 $\left.\mathrm{cm}^{3-1}\right)$, respectively). Whereas, the third treatment did not differ significantly (4.73 gm.100 $\left.\mathrm{cm}^{3-1}\right)$ as compared with other experimental treatments at the first month. Table (3) also shows that there were no significant differences $(\mathrm{P}<0.05)$ in the serum protein concentration among different experimental treatments at the second and third months.

Table (3): Effect of adding different levels of saponins on serum glucose and total protein concentrations at different periods (Mean \pm SD).

\begin{tabular}{|c|c|c|c|c|c|c|}
\hline \multirow{2}{*}{$\begin{array}{c}\text { Treatments } \\
\text { (Saponin level) }\end{array}$} & \multicolumn{3}{|c|}{$\begin{array}{l}\text { Glucose concentration } \\
\text { mg. }\left(100 \mathrm{~cm}^{3}\right)^{-1}\end{array}$} & \multicolumn{3}{|c|}{$\begin{array}{l}\text { Total protein concentration } \\
\left.\left.\qquad \mathrm{g} .100 \mathrm{~cm}^{3}\right)^{-1}\right)\end{array}$} \\
\hline & $1^{\text {st }}$ month & $2^{\text {nd }}$ month & $3^{\text {rd }}$ month & $1^{\text {st }}$ month & $2^{\text {nd }}$ month & $3^{\text {rd }}$ month \\
\hline \multirow{2}{*}{$\begin{array}{l}0 \mathrm{mg} \cdot \mathrm{kg}^{-1} \text { feed } \\
(\text { Control) }\end{array}$} & 50.41 & $51.86^{\mathrm{b}}$ & $55.01^{\mathrm{b}}$ & $4.62^{b}$ & 4.95 & 5.01 \\
\hline & \pm 2.04 & \pm 1.45 & \pm 1.37 & \pm 0.07 & \pm 0.12 & \pm 0.32 \\
\hline \multirow{2}{*}{$60 \mathrm{mg} \cdot \mathrm{kg}^{-1}$ feed } & 51.27 & $53.13^{b}$ & $55.09^{b}$ & $4.65^{b}$ & 5.02 & 5.05 \\
\hline & \pm 1.86 & \pm 3.12 & \pm 1.98 & \pm 0.08 & \pm 0.24 & \pm 0.23 \\
\hline \multirow{2}{*}{$120 \mathrm{mg} \cdot \mathrm{kg}^{-1}$ feed } & 52.38 & $53.60^{\mathrm{b}}$ & $59.00^{b}$ & $4.73^{\mathrm{ab}}$ & 5.25 & 5.19 \\
\hline & \pm 3.05 & \pm 3.12 & \pm 0.90 & \pm 0.01 & \pm 0.34 & \pm 0.59 \\
\hline \multirow{2}{*}{$180 \mathrm{mg} \cdot \mathrm{kg}^{-1}$ feed } & 51.14 & $57.24^{\mathrm{a}}$ & $60.61^{\mathrm{a}}$ & $4.83^{\mathrm{a}}$ & 5.45 & 5.22 \\
\hline & \pm 2.39 & \pm 1.16 & \pm 1.95 & \pm 0.09 & \pm 0.50 & \pm 0.51 \\
\hline
\end{tabular}

- Vertically different letters mean significant differences at $P<0.05$ level.

\section{Cholesterol and triglycerides}

Results presented in table (4) indicated that there were no significant differences in the serum concentration of both cholesterol and triglycerides among different experimental treatments as affected by addition of saponins at different levels $(0,60,120$, and $180 \mathrm{mg} \cdot \mathrm{kg}^{-1}$ dry matter). At the first month, serum concentrations of cholesterol were $53.60,51.83,50.30$, and $50.40 \mathrm{mg} .\left(100 \mathrm{~cm}^{3}\right.$ -1), respectively. While the values of triglycerides were $63.23,62.04,62.48$, and $63.79 \mathrm{mg} \cdot 100^{-1} \mathrm{~cm}^{3}$ respectively. Table (4) also shows that there were no significant differences in the serum concentrations of both cholesterol and triglycerides at the second and third months among different experimental treatments due to addition of saponins. These results are similar to those obtained by Aazami et al. (2013) when they added saponins at different levels $(0,100$ 
and 200) mg. $\mathrm{kg}^{-1}$ dry matter to sheep diets the serum concentration of triglycerides. and no significant differences were found in

Table (4): Effect of adding different levels of saponins on serum cholesterol and triglyceride concentrations in lamb serum at different periods (Mean \pm SD).

\begin{tabular}{|r|c|c|c|c|c|c|}
\hline Treatments & \multicolumn{3}{|c|}{ Cholesterol $\left(\mathrm{mg} .100 \mathrm{~cm}^{3-1}\right)$} & \multicolumn{3}{c|}{ Triglyceride $\left(\mathrm{mg} .100 \mathrm{~cm}^{3-1}\right)$} \\
\cline { 2 - 7 }$($ Saponin level $)$ & $1^{\text {st }}$ month & $2^{\text {nd }}$ month & $3^{\text {rd }}$ month & $1^{\text {st }}$ month & $2^{\text {nd }}$ month & $3^{\text {rd }}$ month \\
\hline 0 mg.kg-1 feed & 53.60 & 56.29 & 58.74 & 63.23 & 66.13 & 67.53 \\
$\left(\mathrm{Control}^{-}\right)$ & \pm 6.78 & \pm 5.50 & \pm 3.59 & \pm 3.37 & \pm 2.44 & \pm 1.54 \\
\hline \multirow{2}{*}{$60 \mathrm{mg} . \mathrm{kg}^{-1}$ feed } & 51.83 & 55.06 & 57.10 & 62.04 & 65.67 & 66.67 \\
& \pm 4.14 & \pm 2.70 & \pm 3.40 & \pm 2.60 & \pm 2.26 & \pm 3.68 \\
\hline \multirow{2}{*}{$120 \mathrm{mg} . \mathrm{kg}^{-1}$ feed } & 50.30 & 54.78 & 55.16 & 62.48 & 65.38 & 66.26 \\
& \pm 4.46 & \pm 4.20 & \pm 3.68 & \pm 6.17 & \pm 5.00 & \pm 4.80 \\
\hline \multirow{2}{*}{$180 \mathrm{mg} . \mathrm{kg}^{-1}$ feed } & 50.40 & 53.76 & 55.36 & 63.79 & 64.56 & 65.50 \\
& \pm 1.45 & \pm 6.52 & \pm 5.09 & \pm 3.51 & \pm 3.59 & \pm 2.65 \\
\hline
\end{tabular}

- There are no significant differences among different treatment means.

\section{Conclusion}

It can be concluded that adding saponins at $180 \mathrm{mg} \cdot \mathrm{kg}^{-1}$ dry matter increases the body weight at the second and third months of the study (34.35 and $40.36 \mathrm{~kg}$, respectively) and gain (17.47 vs $15.03 \mathrm{~kg}$ for control). Feed conversion ratio of the $180 \mathrm{mg} \cdot \mathrm{kg}^{-1}$ of saponin treatment was $5.52 \mathrm{vs} .6 .24 \mathrm{~kg}$ feed. $\mathrm{kg}^{-1}$ for the control treatment. Serum glucose and protein concentrations also showed an improvement with the addition of saponin specially at level of $180 \mathrm{mg} \cdot \mathrm{kg}^{-1}$. The values were 57.24 and $4.83 \mathrm{~g}\left(100 \mathrm{~cm}^{3}\right)^{-1}$ respectively. Those of control group were 51.86 and $4.62 \mathrm{~g} .100 \mathrm{~cm}^{3-1}$ respectively.

\section{Acknowledgements}

We are grateful to all staff in the Department of Animal Production, College of Agriculture, University of Basrah for tremendous help.

\section{Conflicts of interest}

The authors-declare-that they-have-noconflict of interests.

\section{Ethical approval}

All applicable institutional, national and international guidelines for the care and use of animals were followed.

\section{References}

Aazami, M.H.; Tahmasbi, A.M.; Ghaffari, M.H.; Naserian, A.A.; Valizadeh, R. \& Ghaffari, A.H. (2013). Effects of saponins on rumen fermentation, nutrients digestibility, performance, and plasma metabolites in sheep and goat kids. Ann. Res. Rev. Biol., 3(4): 596-607.

Budan, A.; Tessier, N., Saunier, M.; Gillmann, L.; Hamelin, J.; Chicoteau, P. \& Guilet, D. (2013). Effect of several 


\section{Abdullah \& Al-Galbi/ Basrah J. Agric. Sci., 33(1): 17-25, 2020}

saponin containing plant extracts on rumen fermentation in vitro, Tetrahymena pyriformis and sheep erythrocytes. J. Food, Agric. Environ., 11(2): 576-582.

Hussien, S.A. \& Awad, Z.J. (2014). Isolation and characterization of triterpenoid saponin hederacoside $\mathrm{C}$. present in the leaves of Hedera helix $\mathrm{L}$. cultivated in Iraq. IJPS, 23(2): 33-41.

Khalifa, E.I.; Hassanien, H.A.; Mohamed, A.H. \& Hussein, A.M. (2014). Effects of using Yucca schidigera powder as feed additive on productive and reproductive efficiency of Zaraibi dairy goats. Egyp. J. Sheep Goat Sci., 9(2): 9-21.

Liu, C.; Qu, Y.H.; Guo, P.T.; Xu, C.C.; Ma, Y. \& Luo, H.L. (2018). Effects of dietary supplementation with alfalfa (Medicago sativa L.) saponins on lamb growth performance, nutrient digestibility, and plasma parameters. Anim. Feed Sci. Tech., 236: 98-106. https://doi.org/10.1016/j.anifeedsci.2017. 12.006

Liu, Y.; Ma, T.; Chen, D.; Zhang, N.; Si, B.; Deng, K. \& Diao, Q. (2019). Effects of tea saponin supplementation on nutrient digestibility, methanogenesis, and ruminal microbial flora in dorper crossbred ewe. Animals, 9(1): 29-39. https://doi.org/10.3390/ani9010029

Mao, H.L.; Wang, J.K.; Zhou, Y.Y., \& Liu, J.X. (2010). Effects of addition of tea saponins and soybean oil on methane production, fermentation and microbial population in the rumen of growing lambs. Livest. Sci., 129(1-3): 56-62. https://doi.org/10.1016/j.livsci.2009.12.0 11

Nasri, S.; Salem, H.B.; Vasta, V.; Abidi, S.; Makkar, H.P.S. \& Priolo, A. (2011). Effect of increasing levels of Quillaja saponaria on digestion, growth and meat quality of Barbarine lamb. Anim. Feed Sci. Tech., 164(1-2): 71-78. https://doi.org/10.1016/j.anifeedsci.2010. 12.005

Sliwinski, B.J. (2004). Efficacy of plant extracts rich in tannins, saponins, lignin or essential oils as feed supplements in ruminants $\mathrm{Ph}$. D. Thesis, Naturwissenschaften, Eidgenössische Technische Hochschule, ETH Zurich. 145pp. https://doi.org/10.3929/ethz-a004702544

SPSS (2016). Statistical Packages of Social Sciences. IBM Corp. Released 2016. IBM SPSS Statistics for Windows, Version 24.0. Armonk, NY: IBM Corp. https://www.ibm.com/analytics/spssstatistics-software

Sun, D.S.; Jin, X.; Shi, B.; Xu, Y. \& Yan, S. (2017). Effects of Yucca schidigera on gas mitigation in livestock production: A review. Braz. Arch. Biol. Technol., 60: 115. http://dx.doi.org/10.1590/1678-43242017160359.

Szumacher-Strabel, M. \& Cieślak, A. (2010). Potential of Phyto-factors to mitigate rumen ammonia and methane production. J. Anim. Feed Sci., 19(3): 319-337.

https://doi.org/10.22358/jafs/66296/2010. 
تأثير صابونين ورق الثاي على بعض المعايير الانتاجية والبيوكيمياوية في مصل الدم في الحملان العواسية الانية

رشيد حميد عبد الله و هناء علي جبار الغالبي•

قسم الانتاج الحيو اني، كلية الزر اعة، جامعة البصرة، العراق

المستخلص: أجريت الدراسة الحالية في أحد الحقول الخاصة بمحافظة واسط للفترة من 2019/1/22 إلى 2019/5/11.

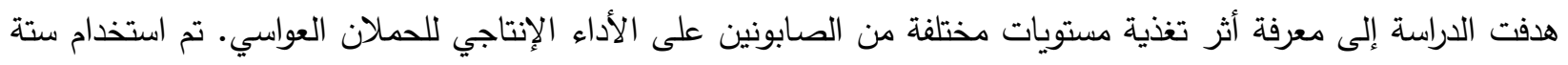

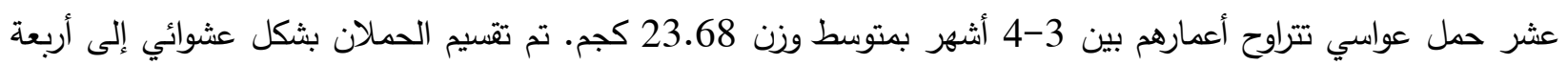

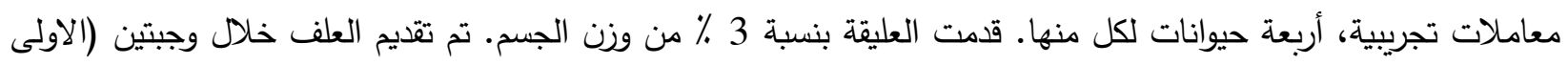
عند 8 صباحا والثانية عند 4 مساءا). كانت المعاملة الأولى هي السيطرة (بدون إضافة)، اما المعاملات الثانية والثالثة الثاتية

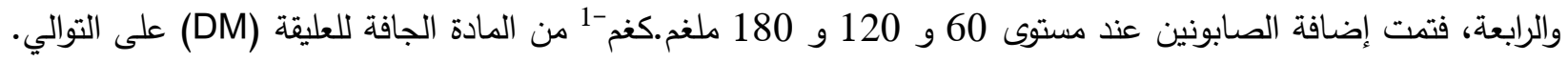

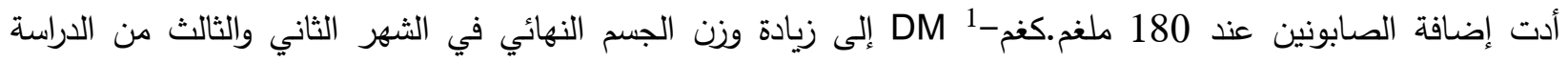

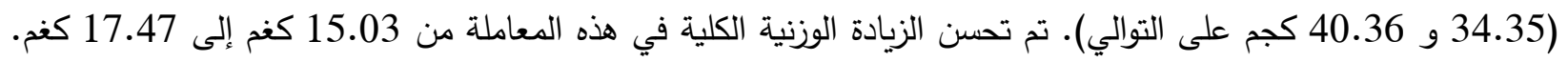

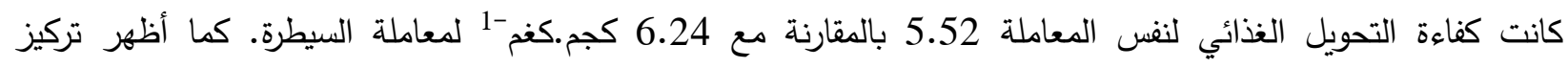

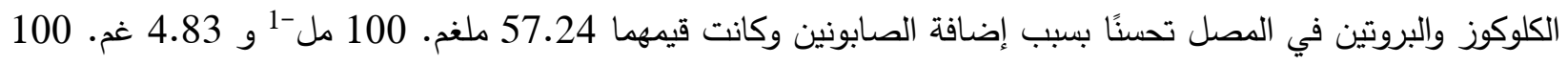

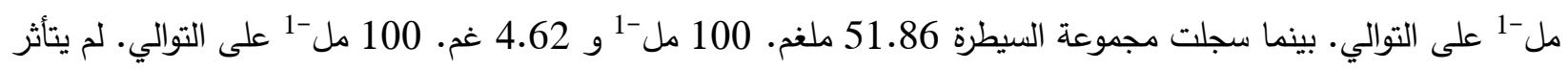

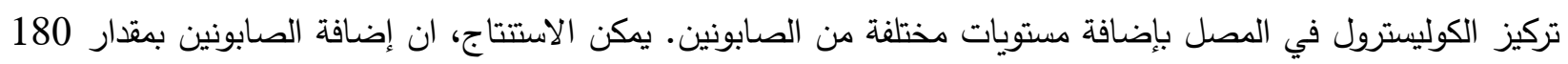

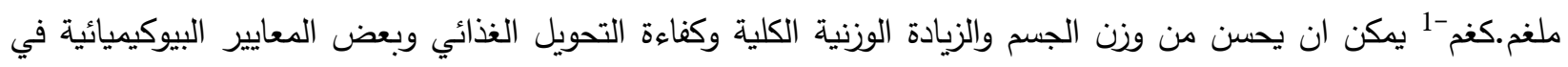

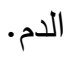
الكلمات المفتاحية: حملان العواسي، المصل، الصابونين، الزيادة الوزنية، كفاءة التحويل الغذائي. 